Türkiye Tarımsal Araştırmalar Dergisi
http://dergi.siirt.edu.tr $\begin{aligned} & \text { Turk J Agric Res } \\ & \text { (2015) 2: 28-39 } \\ & \text { TÜTAD } \\ & \text { ISSN: 2148-2306 }\end{aligned}$

\title{
Madendere Havzasında Fizyoğrafik Faktörlerin ve Bazı Fiziko-Kimyasal Toprak Özelliklerinin Belirlenmesi ve Haritalanması"
}

\author{
Zübeyde GENÇ, Orhan DENGIZZ* \\ Ondokuz Mayıs Üniversitesi, Ziraat Fakültesi, Toprak Bilimi ve Bitki Besleme Bölümü, Samsun, TÜRKIYYE
}

\begin{abstract}
Geliş Tarihi/Received: 01.03 .2015
Kabul Tarihi/Accepted: 18.03 .2015

**Sorumlu Yazar/Correspondence: o_dengiz@hotmail.com

Özet: Bu araştırmanın amacı, Madendere Havzası havza karakteristiklerinin belirlenmesi ve havza içerisinde dağılım gösteren farklı toprakların fiziksel, kimyasal ve morfolojik özelliklerinin incelenmesi, sınıflandırılması ve haritalanmasıdır. Araştırma alanı Kocaeli iline bağlı Kartepe'nin kuzey-doğusunda ve Kartepe Merkeze 14 km uzaklıkta yer almakta olup, 4515500-4518000 K ve 262400-264800 D (UTM-m) koordinatları arasındadır. Araştırma alanı yaklaşık $5.5 \mathrm{~km}^{2}{ }^{2}$ dir. Farklı topoğrafik özelliklere (düz, dalgalı, dağlık) sahip olan alan içerisinde özellikle tepelik ve dalgalı fizyoğrafya hâkim durumdadır. Deniz seviyesinden yükseklik ortalama $130 \mathrm{~m}$ ile $440 \mathrm{~m}$ arasında değişmektedir. Yıllık ortalama yağış ve sıcaklık durumu ise sırasıyla $730.4 \mathrm{~mm}$ ve $11.3{ }^{\circ} \mathrm{C}$ 'dir. Arazi gözlemleri ve topoğrafik, jeolojik ve arazi kullanım durumlarının incelenmesinden sonra, 12 toprak profil çukuru kazılmış ve bunlardan 10 tanesinin farklı olduğu belirlenmiştir. Detaylı olarak yürütülen arazi gözlemlerinde burgu ile grit yöntemi ve serbest tarama yöntemleri kullanılmıştır. Her bir profilden genetik horizon esasına göre toprak örnekleri alınmış ve laboratuvarda analizleri yapılmıştır. Laboratuvar analiz sonuçları ve toprak taksonomisine göre topraklar tanımlanmış ve sınıflandırılmışlar. Topraklar 4 ordo, 4 alt ordo, 6 büyük grup, 10 alt gurup içerisine yerleştirilmiş̧ir. 10 toprak serisi ve bunlara ait sınırlar 1:25.000 ölçekli harita üzerine aktarılmıştır. Bunlardan 2 tanesi genç toprak özellikleri taşıması nedeniyle Entisol, 6 tanesi Inceptisol, 1 tanesi Alfisol ve 1 tanesi ise Ultisol olarak sınıflandırılmıştır. Araştırma alanı içerisinde İsmailinyeri serisi (\% 1.9) en küçük alana sahip iken Gürgenlikdere serisi (\% 22.1) en fazla yayılım alanına sahiptir. Buna ilaveten araştırma alanda belirlenen bazı toprak sorunları hakkında da önerilerde bulunulmuştur.
\end{abstract}

Anahtar Kelimeler: Toprak etüt ve haritalama, toprak sınıflama, havza karakteristikleri, Madendere Havzası

\section{Determination of Physiographic Factors and Some Physico-Chemical Soil Properties and Mapping in Madendere Watershed}

\begin{abstract}
The aim of this research was to determine the basin characteristics and physical, chemical and morphological properties, classification and mapping of different soils in Madendere Watershed. The study area is located northeastern part of Kocaeli-Kartepe district and it is $14 \mathrm{~km}$ from Kartepe center, coordinated as $4515500-4518000 \mathrm{~N}$ ve $262400-264800 \mathrm{E}$ (UTM-m). The study area covers approximately $5.5 \mathrm{~km}^{2}$. The study area consists of various topographic features (flat, hilly, rolling etc.). Hilly and rolling physiographic units are particularly common in the study area. Elevation varies from $130 \mathrm{~m}$ to $440 \mathrm{~m}$ above sea level. Average annual precipitation and temperature are $730.4 \mathrm{~mm}$ and $11.3{ }^{\circ} \mathrm{C}$, respectively. After examination of topographic, land use, geologic and geomorphologic maps and land observation, 12 soil profile pits were excavated and determined that 10 of them are different from each other in the study area. Detailed land observations were done with grid method and auger examinations. The soil samples were taken from each profile based on genetic horizons and their analyses were done in the laboratory. According to the results of laboratory analyses by taking into consideration of soil taxonomy, these soils were classified and described. The soils were grouped under 4 order, 4 suborder, 6 great groups and 10 subgroups within 10 soil series and soil boundaries were shown on the 1:25.000 scale map. Two of ten soil series
\end{abstract}

*Bu çalışma Ondokuz Mayıs Üniversitesi Fen Bilimleri Enstitüsü Yüksek Lisans Tez çalışmasından üretilmiştir. 
were classified as Entisol due to their young age and six are Inceptisol and two were classified as Alfisol and Ultisol. Whereas Gürgenlikdere series has the largest area (22.1\%), İsmailinyeri series has the smallest area in the study area (1.9\%). In addition, some necessary recommendations were given to solve some soil problems in this study.

Keywords: Soil survey and mapping, soil classification, basin characteristics, Madendere Watershed

\section{Giriş}

Nüfustaki hızlı artışa paralel olarak insanoğlunun istekleri artmaya ve çeşitlilik göstermeye başlamıştır. Gereksinimlerdeki büyüme, doğal kaynakların kullanımı üzerinde bir baskı kurmakta ve yenilebilen doğal kaynakların; özellikle toprak ve su kaynaklarının yıpranmasına, isteklere cevap veremeyecek ölçüde yanlış ve aşırı kullanılmasına, hatta ekolojik dengedeki bozulmalara, dolayısıyla doğal taşkınlarla can ve mal kayıplarına neden olmaktadır. Aslında yenilenebilir bir doğal kaynak olan toprak ve arazilerimiz geri dönüşümü çok zor hatta imkânsız hale gelebilmektedir. Başta insanların başlatıp hızlandırdı̆̆ zaman kaybedilmeden en kapsamlı çalışma birimi olan sürdürülebilir havza planlama çalışmalarının ele alınması, yaşamın ve ekolojinin sürdürebilirliği için önkoşuldur. Havzalar, insanların doğal kaynak kullanımlarında orman, mera tarım alanları gibi yaşamsal alanları içermelerinin yanı sıra barındırdıkları ekolojik çeşitlilikleri ile de yaşamda önemli yerleri bulunmaktadır.

Yeryüzü üzerinde arazi, topoğrafik bakımdan irili ufaklı birçok havzalardan oluşmaktadır. Bu nedenle de arazi üzerindeki herhangi bir nokta mutlaka belli bir havzanın içerisinde yer alır. Çeşitli fiziksel, hidrolojik ve ekolojik özellikleri bakımından birer topoğrafik ve hidrolojik arazi birimi niteliğinde olan yağış havzaları, aynı zamanda birer planlama ve geliştirme birimleri olarak da düşünülmekte ve kullanılmaktadır.

Bir havzanın korunması ve sorunlarının giderilmesi için yapılacak öneriler, planlamalar ve ıslah gibi çalışmalarında her şeyden önce o havzanın tüm karakteristik özelliklerinin tanınması, sorunlarının tespit edilmesi ve gerekli öneri ve önlemlerin bu özelliklere göre yapılması gerekir. $\mathrm{Bu}$ işlemin gerçekleştirilebilmesinde havza amenajman planları ön plana çıkarken, havza amenajman planlarında da başvurulacak en önemli kaynaklardan birisi de o havzaya ait toprak veritabanı ve toprak haritalarıdır. Toprak etüt ve haritalama çalışmaları sonucu üretilen toprak haritaları ve bununla ilişkili sunulan raporlar kullanıcılar için önemli veri kaynaklarını oluşturmaktadır. $\mathrm{Bu}$ veri tabanı arazi değerlendirme ve tarımsal planlamalarda, çevresel etkilerin modellenmesinde, değişik mühendislik dallarında ve doğal kaynakların planlanması ve korunması çalışmalarında kullanılmaktadır.
Raporların doğruluğu, detay ve içerdiği ilave bilgilerin zenginliği, bu amaçla sonraki kullanımlar için geçerli sonuçlar alınmasını sağlamaktadır (Rogowski ve Wolf, 1994).

Ülkemiz ve diğer ülkelerdeki toprak haritalarının hazırlanmasındaki metot ve üretilen haritaların kaliteleri açısından da farklılıklar mevcuttur. ABD'de tarım yapılan alanların tamamında, özel alanların \% 91'inde ve tüm ülke için \% 76'lı kısmında toprak etütleri tamamlanmıştır. Yayınlanan raporlar genellikle 1:15.840 veya $1: 24.000$ ölçeğinde olup, oldukça kapsamlı bilgiler içermektedir. Avrupa ülkelerinde de benzer durum söz konusudur (Bathgate ve Duram, 2003). Ülkemizde ise (Mülga) Köy Hizmetleri Genel Müdürlüğü'nce belirli bölgeler için 1:100.000 ölçekli il envanter raporları ve 1:200.000 havza raporları eski sınıflama sistemine göre yetmişli yılların başlarında hazırlanmış toprak haritaları (bazı küçük alanlarda yapılan münferit çalışmalar ve birkaç büyük proje hariç-GAP) tek veri kaynağıdır. $\mathrm{Bu}$ haritalardan sadece toprak derinliği, eğim, erozyon derecesi, drenaj, tuzluluk, alkalilik, taşlılık, kayalılık, arazi kullanım kabiliyet sınıfi, alt sınıfı ve arazi kullanım durumu bilgileri sağlanabilmektedir. $\mathrm{Bu}$ haritalar sağladıkları bilgilerin yeterli ve güncel olmamasının yanı sıra ölçekleri nedeniyle detaylı çalışmalar ve planlamalar için kullanılamamaktadır (Akbaş ve Yıldız, 2004). Bu önemli eksikliğin giderilmesi amaciyla (Mülga) Köy Hizmetleri Genel Müdürlüğü tarafindan, 2002 yılında "Türkiye Toprak Veritabanı" adlı proje çalışması başlatılmıştır. Böylece yeni toprak haritaları, ölçülebilir ve gözlenebilir toprak özellikleri içeren, morfometrik esaslara dayalı ve dünyada gelişmiş ülkelerin kullandıkları yeni sınıflandırma sistemine göre oluşturulması planlanmıştı. $\mathrm{Bu}$ proje doğrultusunda bünyesinde bulundurduğu teknik personellerin eğitim çalışmaları yapmış, gerekli alt yapı donanımlarını oluşturmuştu. Fakat süreç içerisinde 5286 Sayılı Köy Hizmetleri Genel Müdürlüğü'nün kaldırılması kanununun çıkmasının ardından kurum 2005 yılında kapatılmasıyla proje ülke çapında faaliyete geçemeden duraksamaya uğramıştır. Ülkemizde genellikle arazilerinin/toprakların tanımlayıcı özellikleri Toprak Koruma ve Arazi Kullanımı Kanunu'ndaki niteliksel gruplamalara göre değil, tüm detayda yapılacak çalışmalara cevap verebilecek güncel, görsel, konumsal ve niceliksel 
verilere göre yapılması gerekmektedir. Bu nedenle, öncelikli olarak sürdürülebilir arazi yönetimleri ve planlamalarının yapılabilmesi için bu şekilde hazırlanmış toprak serileri ve faz düzeylerini dikkate alan detaylı toprak etüt ve haritalama çalışmalarına ihtiyacı duyulmaktadır (Dengiz ve Sarığlu, 2011).

$\mathrm{Bu}$ çalışma ile hedeflenen amaçlar; öncelikle bölgede yeni toprak sınıflandırma sistemine göre toprak etüt ve haritalama çalışmalarının yaygınlaşmasının sağlanmak, Madendere Havzası'na ait temel havza karakteristikleri ve farklı toprak özelliklerini belirleyerek dağılım haritasını oluşturmaktır. Ayrıca havza topraklarına yönelik belirlenen temel toprak sorunlara yönelik çözüm önerilerinin de getirilmesi de hedeflenmiştir.

\section{Materyal ve Yöntem}

\subsection{Materyal}

Madendere Havzası Kocaeli iline bağlı Kartepe'nin kuzey-doğusunda ve Kartepe Merkeze $14 \mathrm{~km}$ uzaklıktadır. Havza sınırları içerisinde sadece Avluburun köyü yer almaktadır. Havzaların büyüklük bakımından sinıflandırması göz önüne alındığı zaman Madendere Havzası yaklaşık 5.5 $\mathrm{km}^{2}$ kapladığı alan ile "küçük havza" kategorisine girdiği anlaşılmaktadır. Deniz seviyesinden yaklaşık 130-440 m yükseklik arasında bulunan havza, 4515500-4518000 K ve 262400-264800 D (UTM-m) koordinatlarında yer almaktadır (Şekil 1). Ayrıca havzanın genel bazı karakteristik özellikleri ise Tablo 1'de verilmiştir.

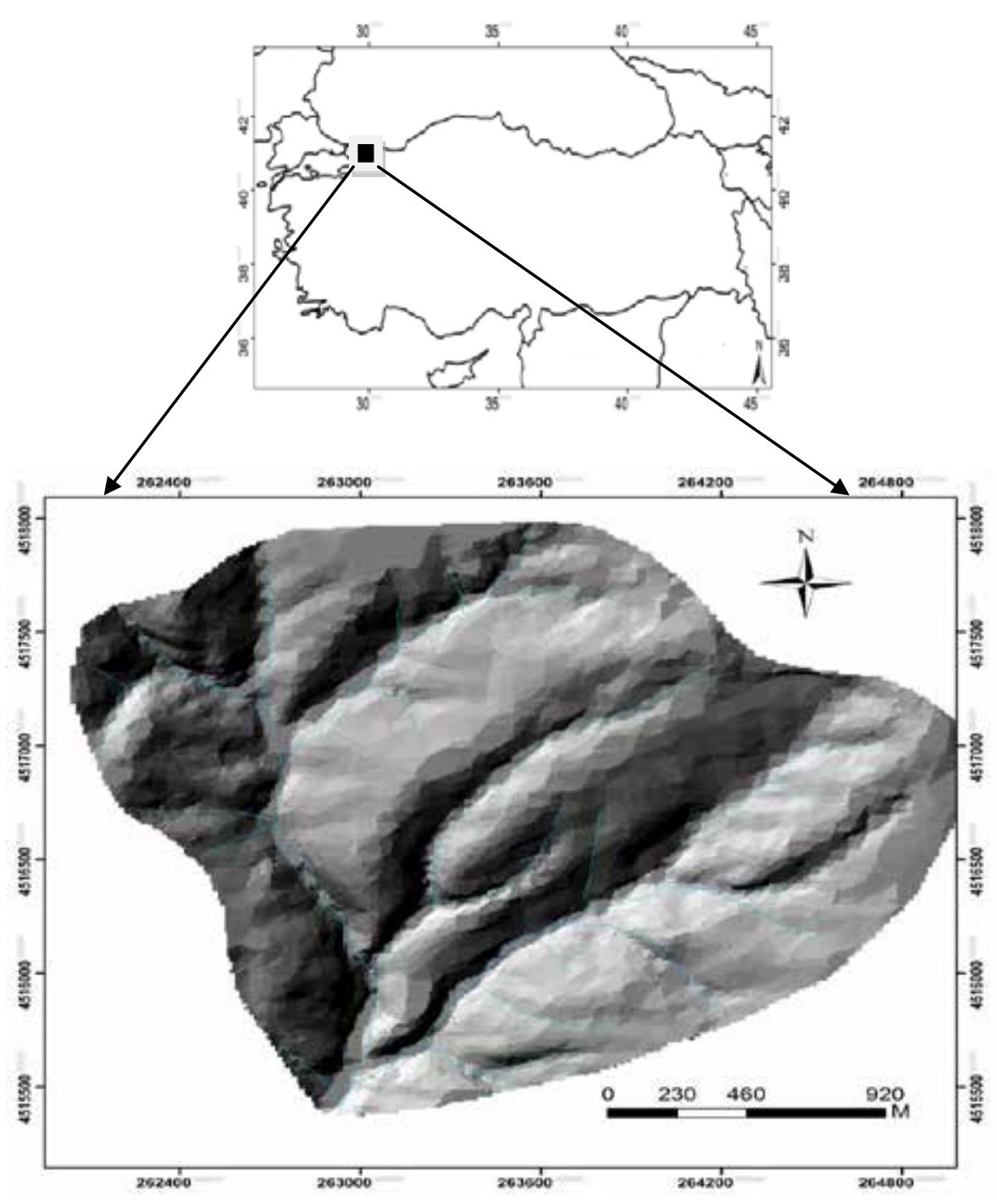

Şekil 1. Çalışma alanı lokasyon haritası 
Tablo 1. Madendere Havzası bazı genel karakteristik özellikleri

\begin{tabular}{ll}
\hline Havza alanı (A) & $5.4652 \mathrm{~km}^{2}$ \\
Havza uzunluğu (LH) & $2.75 \mathrm{~km}$ \\
Havza çevresi & $8.997 \mathrm{~km}$ \\
Havza maksimum yüksekliği (hmax) & $440 \mathrm{~m}$ \\
Havza minumum yüksekliği(hmin) & $130 \mathrm{~m}$ \\
Havza ortalama yükseklik & 312 \\
Havza röliyefi (r) & $535.39 \mathrm{~m}$ \\
Havza yöneyi & güneybatı \\
Havza ortalama eğimi (SH) & $\% 13.86$ \\
Form faktörü (F) & 0.72 \\
Şekil faktörü (Ş) & 1.38 \\
Dairesellik oranı (Rc) & 0.85 \\
Uzama oranı (E) & 0.96 \\
Ana derenin yatay uzunluğu & $3692 \mathrm{~m}$ \\
Oransal reliyef & 0.03 \\
Drenaj yoğunluğu & 6.2 \\
\hline
\end{tabular}

Araştırma alanı yıllık ortalama yağıș miktarı $730.4 \mathrm{~mm}$, y1llık ortalama sıcaklık değeri ise 11.3 ${ }^{\circ} \mathrm{C}$ 'dir (Tablo 2). Toprak Taksonomisi (Anonymous, 1999)'ne göre çalışma alanı ustic nem rejimi ve mesic sicaklik rejimine sahiptir.

$\mathrm{Bu}$ çalışmada, araştırma alanına ait G24a3 paftas1 içerisine giren 1:25.000 ölçekli topoğrafik harita temel altlık kartoğrafik materyal olarak kullanılmış ve sayısallaştırılmıştır (Şekil 2).

Topoğrafik haritaların sayısallaştırılması, toprak veri tabanı ve sayısal toprak haritalarının oluşturulmasında TNT Mips 6.4v ve ArcGIS 9.3v coğrafi bilgi sistemi programları kullanılmıştır.

\subsection{Yöntem}

$\mathrm{Bu}$ araştırma arazi, laboratuvar ve büro çalışmaları olmak üzere farklı 3 aşamadan oluşmuştur. Büro ve laboratuvar çalışmaları Ondokuz Mayıs Üniversitesi Ziraat Fakültesi Toprak Bilimi ve Bitki Besleme Bölümü’nde yer alan coğrafi bilgi sistemi ve uzaktan algılama laboratuvarı ile toprak fiziksel kimyasal analiz laboratuvarında yürütülmüştür. Detaylı temel toprak etüt ve haritalama metodolojisi olarak Soil Survey Manuel (Anonymous, 1993) ve sınıflandırma çalışmalarında Soil Taxonomy (Anonymous, 1999) esas alınmıştır.
İlk aşama olarak ele alınan büro ve ön arazi keşif çalışmalarında; çalışma alanına ait ön veri ve bilgiler ile yardımcı kartoğrafik materyaller temin edilmiş ve değerlendirmeye alınmıştır. Bunlar, bölgeye ait uydu görüntüsü ile iklim değerleri, topoğrafik, toprak ve jeolojik haritalardır. Belirlenecek mevcut bitki deseni ve arazi kullanımı ile topoğrafik haritalardan üretilmiş Sayısal Arazi Modeli (SAM) ve yükseklik haritası kullanılarak alanda yayılım gösteren farklı fizyoğrafik üniteler, eğim, rölyef, bakı ve arazi şekilleri çıkartılmıştır.

Arazi şekli ve arazi örtüsü jeolojik verileri ile birleştirilerek farklı ana materyal ve farklı fizyoğrafya üzerinde oluşmuş topraklar tespit edilmiş ve ön toprak haritası oluşturulmuştur. Ancak çalışma alanının büyük bir kısmını dalgalı ve tepelik araziler oluşturması nedeniyle burada farklılık gösterebilecek toprakların belirlenmesi için açılacak profil çukurların yerleri ön arazi çalışması ve eldeki verilerden yararlanılarak yapılmıştır. Anakaya/anamateryal, arazi kullanımıbitki örtüsü veya topoğrafya farklılaşması çok belirgin olmadığı alanlarda, arazide yapılacak gözlemler ve test sondalamaları sonucu elde edilen bilgilerden yararlanılmıştır. Belirlenen profil çukurlarının koordinatları harita üzerine aktarılmıştır.

İkinci aşama olan arazi çalışmasında ise, daha önceden yapılan büro ve ön arazi çalışmaları sonucu belirlenen olası farklı özellikteki topraklar üzerinde arazide Yer Belirleme Aleti (GPS) kullanarak 12 adet profil çukurları açılmıştır. Farklı toprak profillerinden genetik horizon esasına göre morfolojik tanımlamalar yapılmış ve toprak örnekleri alınmıştır. Alınan toprak örnekleri fiziksel, kimyasal ve verimlilik analizler için laboratuvara getirilmiştir. Arazide toprakların morfolojik özelliklerinin incelenmesi amaciyla dikkate alınan kriterler, örneklemeler ve sınıflandırma için Anonymous (1993, 1999) kullanılmıştır.

Alınan toprak örneklerinde; bünye, Bouyoucous (1951); katyon değişim kapasitesi ve değişebilir katyonlar, Tüzüner (1990); kireç

Tablo 2. Çalışma alanı meteorolojik verileri

\begin{tabular}{|c|c|c|c|c|c|c|c|c|c|c|c|c|c|}
\hline & 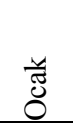 & $\begin{array}{l}\overrightarrow{\tilde{J}} \\
\vec{B} \\
\vec{B}\end{array}$ & $\sum^{\bar{J}}$ & 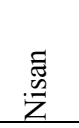 & $\sum_{\Sigma}^{\infty}$ & 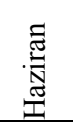 & है & 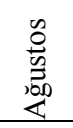 & $\underset{\text { 离 }}{\text { 离 }}$ & $\frac{\text { 吉 }}{I}$ & $\begin{array}{l}\Xi \\
\Xi \\
\underline{\Xi} \\
\underline{\Xi}\end{array}$ & 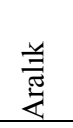 & Yillık \\
\hline $\mathrm{T}^{\circ} \mathrm{C}$ & 0.0 & 2.0 & 5.8 & 11.0 & 15.5 & 19.5 & 22.0 & 21.5 & 18.0 & 12.2 & 6.5 & 1.9 & 11.3 \\
\hline $\mathrm{P}(\mathrm{mm})$ & 92.8 & 82 & 78.9 & 76.3 & 57.7 & 40.3 & 14.6 & 15.1 & 26.6 & 54.7 & 85.4 & 106 & 730.4 \\
\hline
\end{tabular}


$\left(\mathrm{CaCO}_{3}\right)$, Hizalan ve Ünal (1966); pH ve elektriksel iletkenlik (EC), Anonymous (1954); organik madde, Jackson (1958) yöntemlerine göre analizleri yapılmıştır. Son aşama da ise, farklı özelliklere sahip toprakların analiz sonuçları da dikkate alınarak gerekli düzeltmeler yapılmış ve arazi sınırları kesinleştirilerek havzanın 1:25.000 ölçekli temel toprak haritası yapılmıştır.
Detaylı olarak yürütülen toprak etüt ve haritalama çalışmalarında haritalama ünitesi olarak, toprak serileri ve bunların fazları kullanılmıştır. Toprakların fazlara ayrılmasında gözetilen eğim, drenaj, taşlılık, kayalılık, derinlilik ve erozyon gibi faktörler içinde yine Anonymous (1993)'tan yararlanılmıştır.

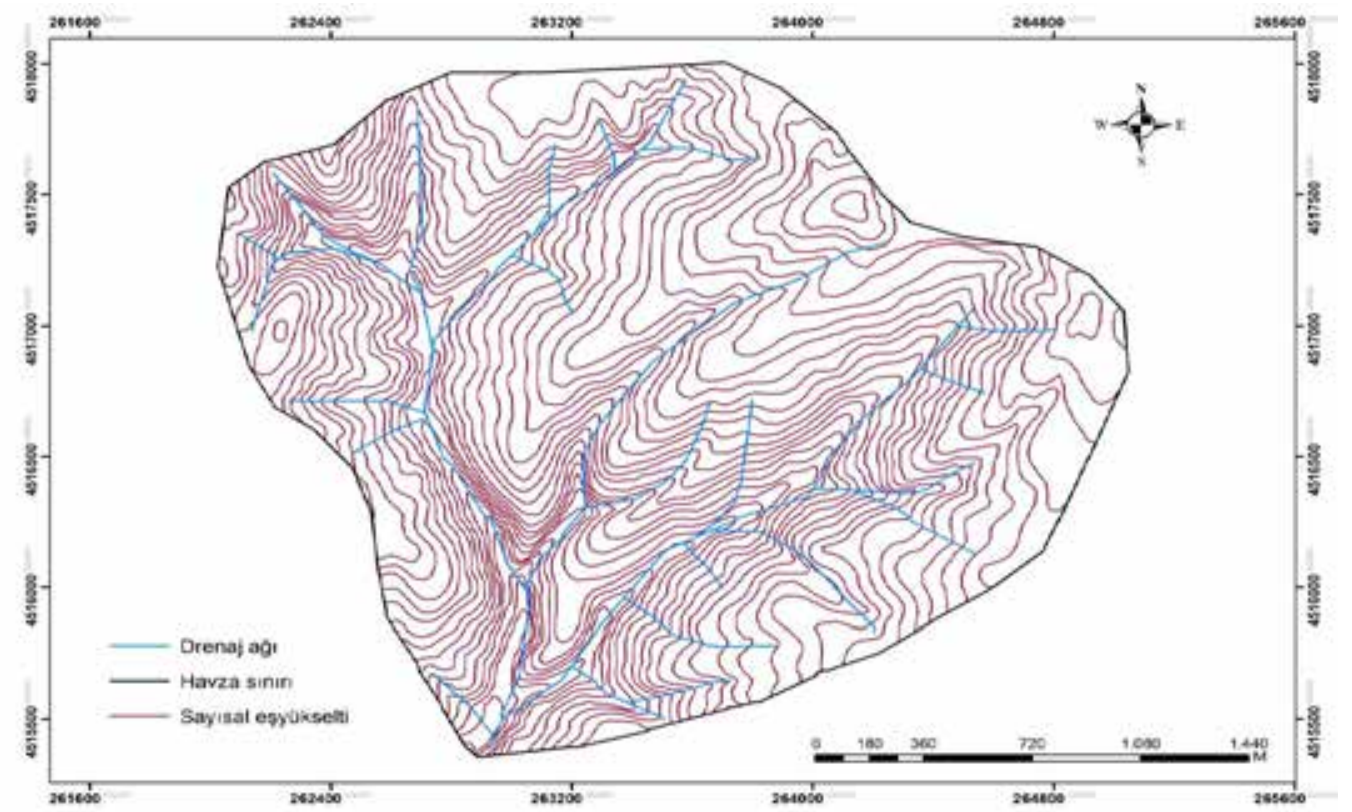

Şekil 2. Çalışma alanına ait sayısal eşyükselti haritası

\section{Bulgular ve Tartışma}

\subsection{Araştırma alanı bakı, yükseklik ve eğim dağılımı}

Madendere Havzası'nın bakı, eğim ve yükseklik haritaları Şekil 3'te verilmiștir. Havzanın maksimum eğim değeri \% 47.7, minimum eğim değeri \% 0'dır. Ortalama eğim ise \% 13.86'dir. Alanın eğim dağılımı ise düz-düze yakın olan (\% 0-2) alan 407.45 ha iken; dik, çok dik ve sarp eğimli alanlar yaklaşık 4566 hektardır. Hafif ve orta dik eğimli alanlar ise yaklaşık 395 hektardır. Ortalama bakısı, $205^{\circ}$ ile güneybatıdır.
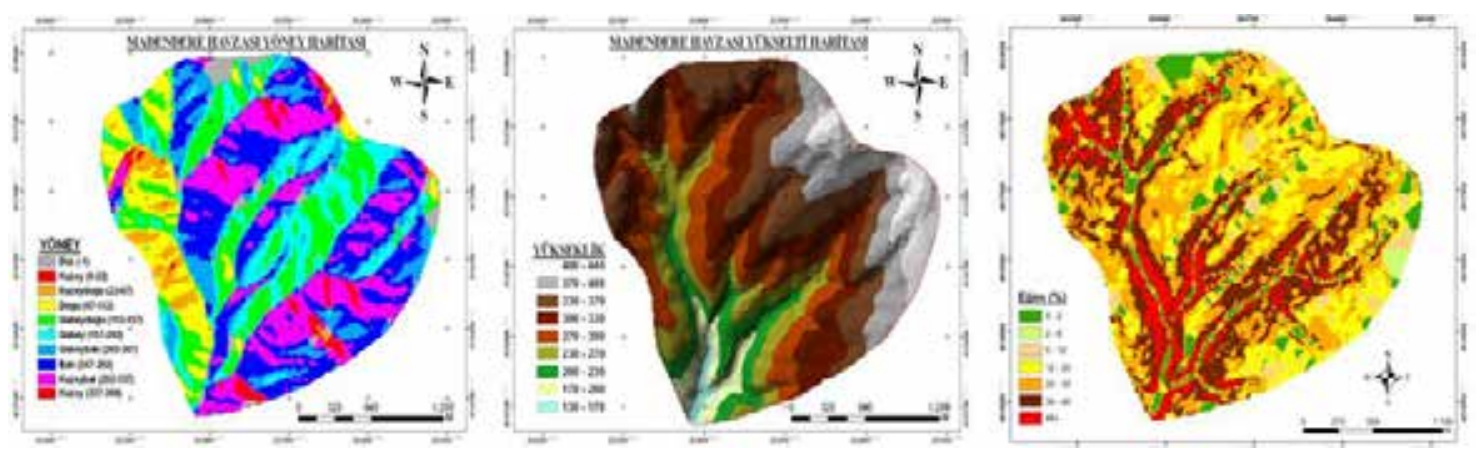

Şekil 3. Madendere Havzası bakı, yükseklik ve eğim haritaları 


\subsection{Madendere Havzası toprak serilerinin morfolojik tanımlamaları, fiziksel ve kimyasal özellikleri}

Analizlerden elde edilen sonuçların ve arazi gözlemlerinin değerlendirilmesi ile çalışma alanına ait 10 farklı toprak serisi tanımlanmıştır. Her bir seriye ait analiz sonuçları Tablo 3'te verilmiştir. Araştırma alanı içerisinde İsmailinyeri serisi (\% 1.9) en küçük alana sahip iken, Gürgenlikdere serisi (\% 22.1) en fazla yayılım alanına sahiptir (Şekil 4).

Toprak taksonomisine göre Typic Dystrustept olarak sınıflandirılan Avluburun serisi, yumuşak, bozuşmaya uğramış kil taşı ana materyal üzerinde oluşmuş, derin ve iyi drenajlı topraklardır. Bu seri 523 da yayılım alanı ile toplam alanın \% 9.6'sını oluşturmaktadır. Yaklaşık \% 6-12 arasında olan orta eğime sahiptirler. Toprakların tuzluluk ve erozyon problemleri yoktur. Bünye yüzeyde kil tın iken, kil miktarı $14 \mathrm{~cm}$ sonrasında bir miktar artmakta, fakat bünye sınıfı değişmemesine karşın 90 cm'den sonra killi bünyeye dönüşmektedir. Bünyedeki bu değişim katyon değişim kapasitesi (KDK) ve yarayışlı su tutma kapasitelerini de etkileyerek artışa neden olmakta ve sırasıyla 27.4$31.2 \mathrm{cmol} \mathrm{kg} \mathrm{k}^{-1}$ ile \% 28.6-30.0 arasında değişmektedir. Topraklar çok az kireçli olup, yüzeyden derinlere doğru yıkanma etkisi ile bu oran daha da azalmakta ve \% 1.60 yüzey toprağında bulunurken, derinlere doğru \% 0.75 'e düşmektedir. Benzer şekilde $\mathrm{pH}$ durumu bazik katyonlardaki yıkanma etkisi ile yüzeyde hafif asit reaksiyon olan 6.12 iken, derinlerde daha düşük pH olan 5.30'a düşmektedir. Organik madde yüzey toprağında çok az düzeylerde olan \% 1.33 iken, bu oran derinlere doğru daha da azalma göstermektedir (Tablo 3). Toprakların profil boyunca ana spektral renkleri 2.5 Y'dir, value ve chroma değerlerinde çok fazla bir değişim yoktur.

Killi kireç taşı-marn ana materyal üzerine oluşmuş Madendere-1 serisi, toprak taksonomisine göre Lithic Ustorthent olarak sinıflandırılmakta ve 197 da alanla toplam alan içerisinde \% 3.6'lık kısmı oluşturmaktadır. Bu alandaki topraklar, pedogenetik horizon oluşumunun oldukça zayıf olması nedeniyle genç topraklar olarak nitelendirilebilir. Genellikle mera olarak kullanılan bu toprak serisi \% 12-20 eğimle dik eğimli alanlardan oluşmakta olup, ayrıca seri kendi içerisinde eğim fazında farklılık göstererek eğimin \% 20'nin üzerine çıktığı çok dik alanları da kapsamaktadır. Gerek eğimin fazla oluşu, gerekse de yüzey bitki örtüsünün azlığı nedeniyle şiddetli erozyona maruz kalan bu seri toprakları sığ derinliğe sahip, kil tın bünyeye sahiptir. Toprak reaksiyonu hafif alkalin olup (7.33), kireç oranları çok yüksektir (yaklaşık \% 22). $\mathrm{Bu}$ nedenle değişebilir katyonlar içerisinde baskın iyonlar kalsiyum ve magnezyumdur. Organik madde içerikleri düşük olmasının yanı sıra profilde derinlik arttıkça azalma göstermektedir (Tablo 3). Topraklarda tuzluluk ve erozyon problemleri yoktur.

Toprak taksonomisine göre Typic Ustorhent olarak sinıflandırılan Madendere-2 serisi, yumuşak, bozuşmaya uğramış kil taşı ana materyal üzerinde oluşmuş, derin ve iyi drenajlı topraklardır. Bu seri 523 da yayılım alanı ile toplam alanın \% 9.6'sını oluşturmaktadır. Yaklaşık $\%$ 6-12 arasında olan orta eğime sahiptirler. Toprakların tuzluluk ve erozyon problemleri yoktur. Bünyedeki tane dağılım oranı profil içerisinde hemen hemen aynı olup, sınıf ise kil tındır. Toprakların bulundukları alanlar çukur topoğrafik pozisyon nedeniyle yüzey suların biriktiği alanlar olması ve zayıf drenaj özellikleri nedeniyle $80 \mathrm{~cm}$ 'den sonra indirgen özellikler olan gleyleşme-renk benekleri görülmüştür. Yüzeydeki granüler strüktür dişında profil içerisinde her hangi bir strüktüral gelişme belirlenememiştir. Yüzeyde topraklar yaklaşık \% 8 ile orta kireçli iken, bu oran yıkanma sonucu azalarak derinlerde 1.6'ya inmektedir. Tüm profil hafif asit karakterli olup, tuzluluk problemleri yoktur. Organik madde yüzey toprağında çok az düzeylerde olan \% $1.56 \mathrm{iken,} \mathrm{bu}$ oran derinlere doğru daha da azalma göstermektedir (Tablo 3). Toprakların profil boyunca ana spektral renkleri 2,5 Y' dir, value ve chroma değerlerinde çok fazla bir değişim yoktur.

Marn ana materyal üzerinde oluşmuş olan Damlaburun-1 Serisi toplam alan içerisinde 256 da alan ile \% 4.7' lik alanı oluşturmaktadır. Toprak taksonomisine göre inceptisol ordosunun Calcic Haplustept alt gurubunda sinıflanmaktadır. Bu seri toprakları \% 12-20 eğimli, dik arazilerden oluşmaktadır. Yüzeyde kil tın bünyeye sahip olan seri toprakları $17 \mathrm{~cm}$ 'den sonra kil miktarındaki artış ile kili bünyeye dönüşmektedir. Dolaysıyla artan kil ile ayrıca bu katta strüktüral bir değişimle beraber yarı köşeli blok yapılar oluşmaktadır. Topraklar drenaj ve yüksek KDK değerine sahiptir. Organik madde sadece yüzeyde \% 2.60 olarak tespit edilmiş, alt derinliklere doğru ise bu oran önemli ölçüde azalma göstermiştir. Tuzluluk problemleri bulunmamaktadır. Kireç toprakta 90 cm derinliğe kadar çok az seviyelerde (\% 1-2) bulunurken, özellikle ana materyal etkisiyle bu oran \% 27'lere çıkmaktadır (Tablo 3).

Toprak taksonomisine göre Typic Dystrustept olarak sınıflandırılan Çayırlıksırtı serisi; ayrışmaya uğramış yumuşak kil taşı üzerinde oluşmuş, derin ve zayıf drenajlı topraklardır. Profil $\mathrm{Ap} / \mathrm{A}_{2} / \mathrm{Bw} / \mathrm{C}$ şeklinde horizon dizilimi göstermektedir. Tanı 


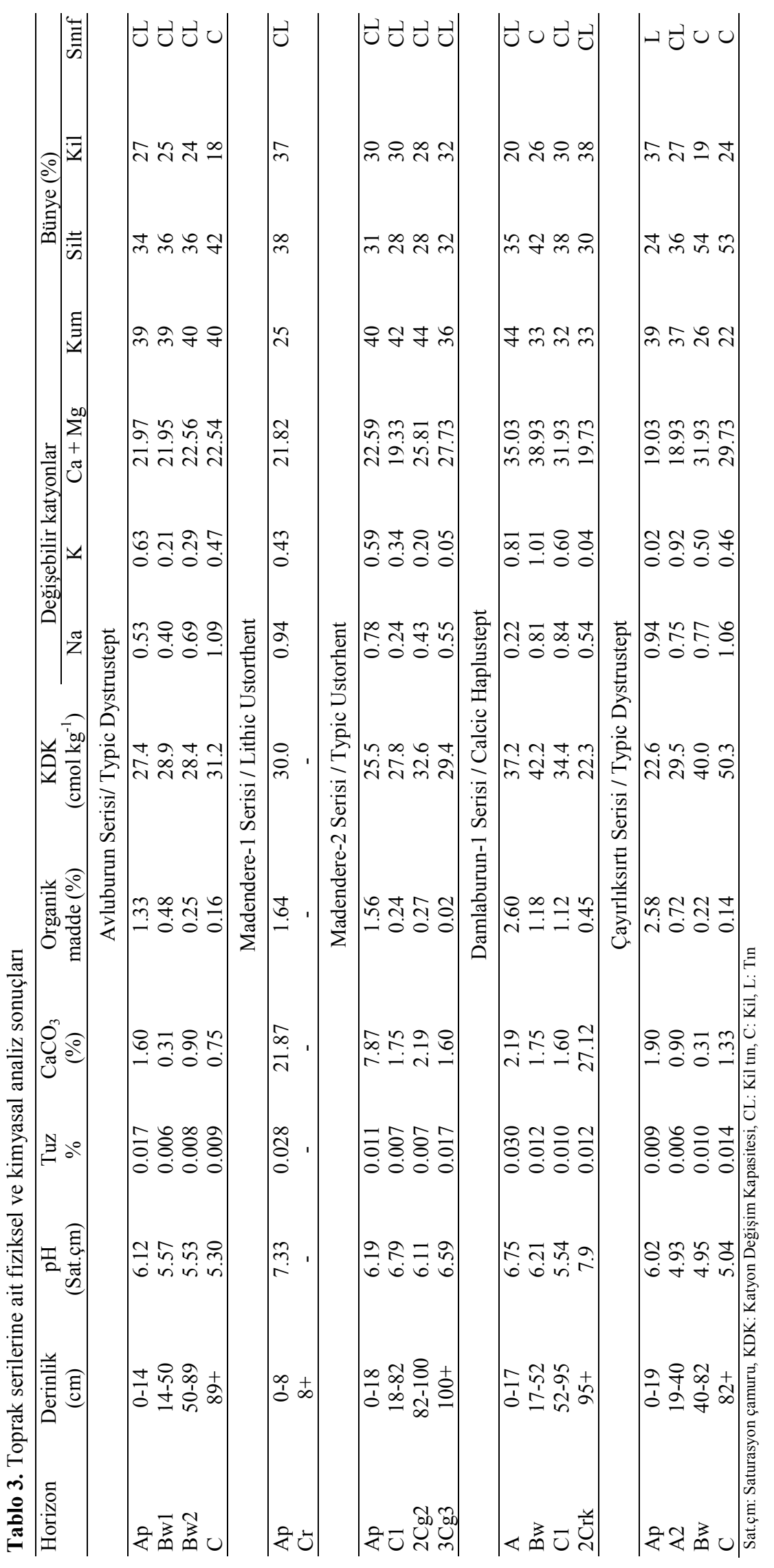




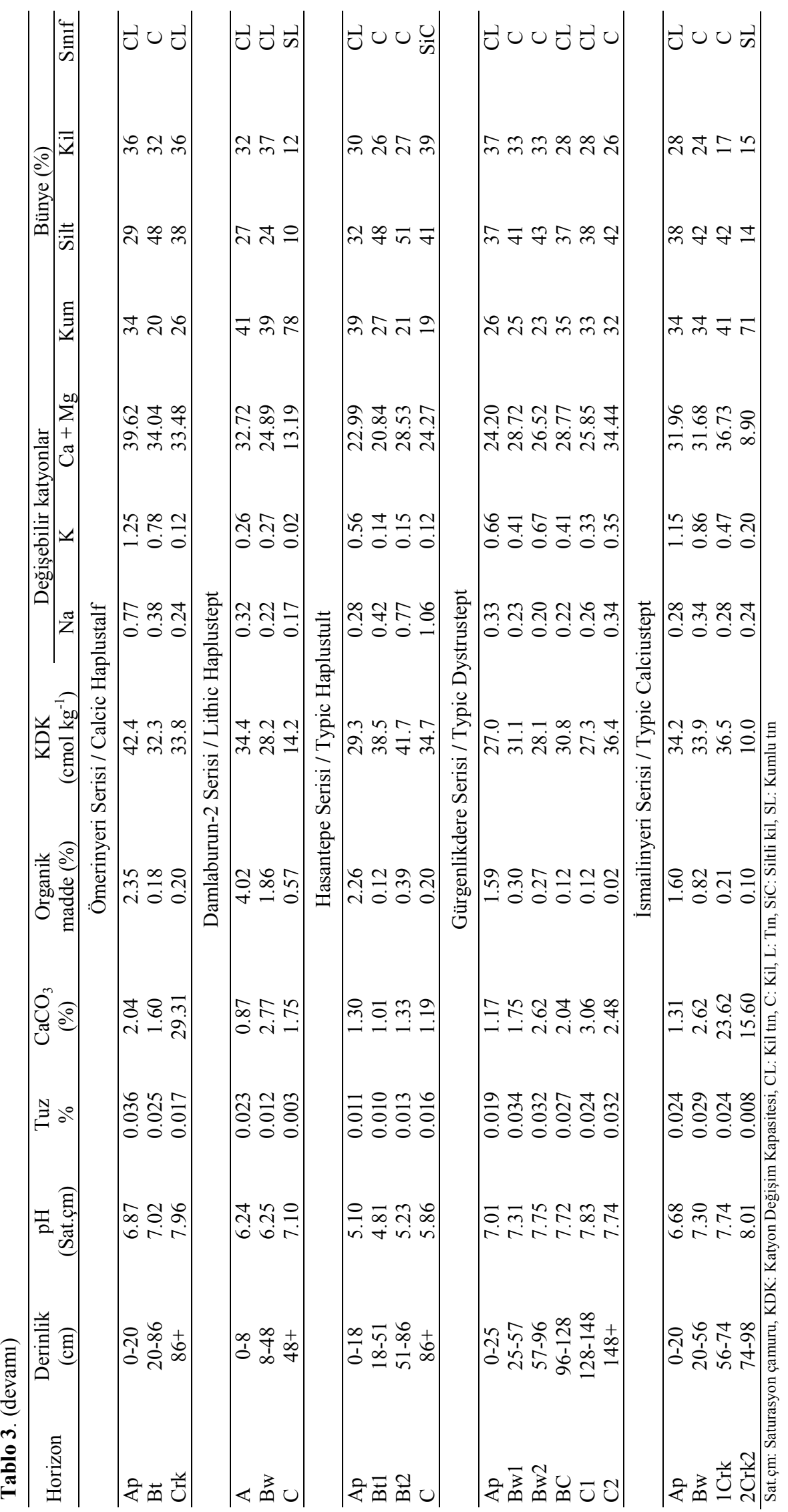




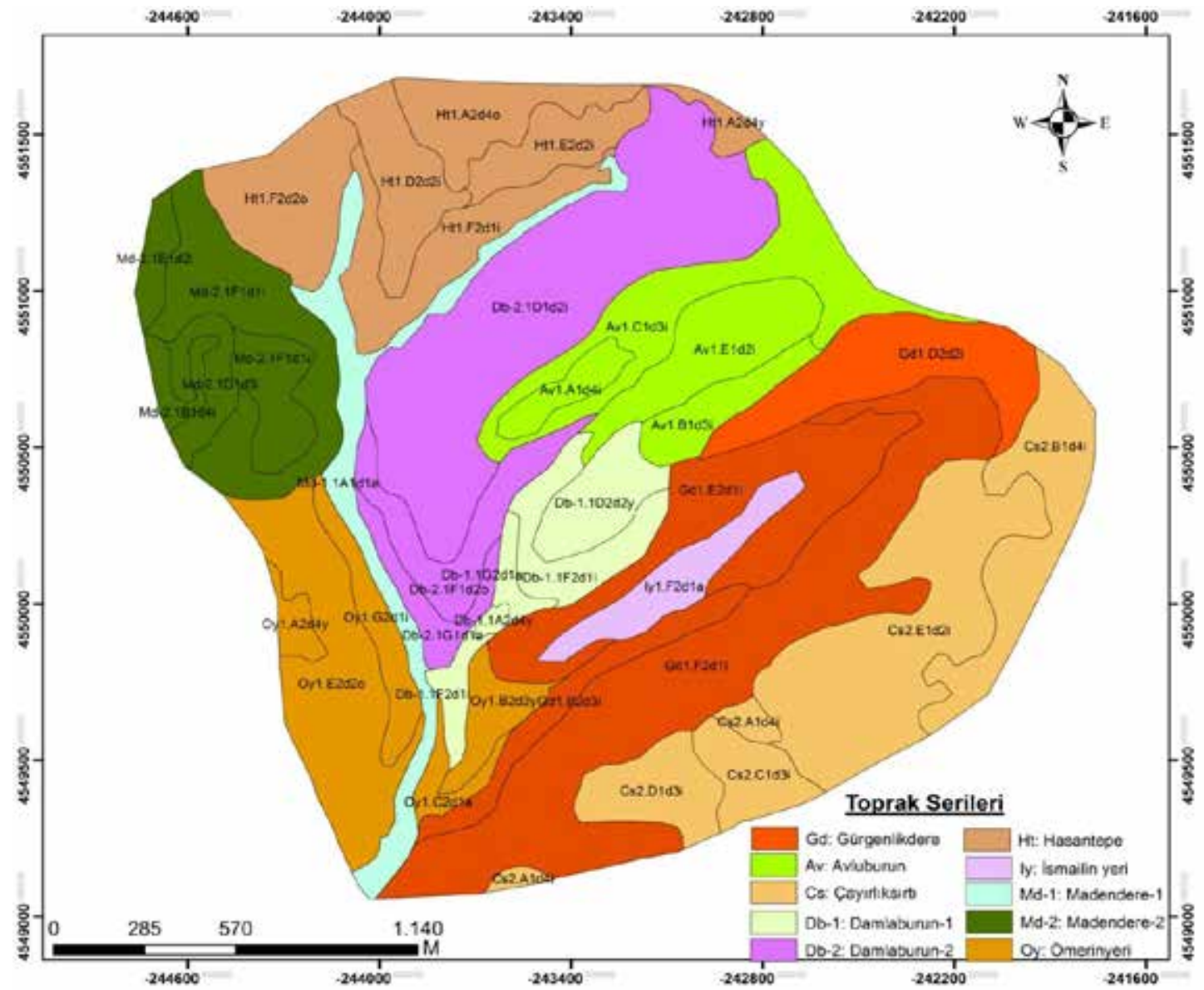

Haritalama Birimi (Ht1.E2d2i): Ht: Toprak Seri sembolü (Hasan Tepe serisi), 1: Üst toprak tekstürü, A: Eğim sınıfi, 2: Alt toprak tekstürü, d2: Derinlik sınıfi, i: Drenaj sınıfi

\begin{tabular}{|c|c|c|c|}
\hline \multicolumn{4}{|c|}{ Haritalama Lejanti } \\
\hline Eğim (\%) & Üst toprak tekstürü & Toprak derinliği $(\mathrm{cm})$ & Drenai \\
\hline 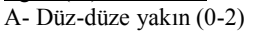 & 1- Kil tın (CL) & d1- Çok sığ $(0-20)$ & i: iyi \\
\hline B- Hafif (2-6) & 2- Tin (L) & d2- S1 $\breve{g}(20-50)$ & y: yetersiz \\
\hline C- Orta (6-12) & 3- Kil (C) & d3- Orta derin $(50-90)$ & a: aşırı \\
\hline D- Dik (12-20) & Alt Toprak Tekstürü & d4- Derin $(90+)$ & o: orta \\
\hline E- Çok dik (20-30) & 1- Kil tın (CL) & & \\
\hline F- Sarp (30-45) & 2-Kil (C) & & \\
\hline G- 45+ & & & \\
\hline
\end{tabular}

Şekil 4. Araştırma alanına ait temel toprak haritası

horizonu olarak bir cambic horizona sahiptir. $\mathrm{Bu}$ alanlardaki topraklarda da genç topraklara nazaran pedogenetik olayların etkisi biraz daha fazladır. $\mathrm{Bu}$ seri 809 da yayılımla toplam alanın \% 14.8 ile en fazla dağılım alanına sahip ikinci büyük serisini oluşturmaktadır. Yayılım gösterdiği alanlar \% 0-2 eğime sahip düzlüklerdir. Yüzeyde profil tın bünyeli iken, derinlere doğru kil miktarı artarak ağır bünyeli olmaktadır. Tüm profil çok az kireçli ve yoğun bir bazik yıkanmasına bağlı olarak da reaksiyon hafif asitten derine doğru kuvvetli aside dönüșmektedir. Toprakların KDK'ları 22.6-50.3 cmol $\mathrm{kg}^{-1}$ ve organik maddeleri yüzeyde \% 2.58 iken, bu oran derinlerde \% 0.14 'lere düşmektedir (Tablo 3). Tuzluluk problemleri bulunmamaktadır.
Toprak taksonomisine göre Calcic Haplustalf olarak sınıflandırılan Ömerinyeri serisi; ayrışmaya uğramış yumuşak kil taşı-marn üzerinde oluşmuş, derin ve zayıf drenajlı topraklardır. Profil $\mathrm{Ap} / \mathrm{Bt} / \mathrm{Crk}$ şeklinde horizon dizilimi göstermektedir. Yüzey altı tanı horizonu olarak bir argillik horizonun yanı sira kalsifikasyon olayı sonucu $80 \mathrm{~cm}$ derinlikte sekonder kireç birikimleri bulunmaktadır. Bu alanlardaki topraklarda genç topraklara nazaran bir kil yıkanım ve birikim söz konusu olması nedeniyle pedogenetik olayların etkisi daha fazladır. Bu seri 441 da yayılım alanıyla toplam alanın \% 8.1'ni oluşturmaktadır. Yayılım gösterdiği alanlarda genellikle orta eğimli olup \% 6-12 arasında değişmektedir. Yüzeyde profil kil tın bünyeli iken, derinlere doğru özellikle 
20-86 cm arasında kil birikimi artarak ağır bünyeli olmaktadır. Tüm genetik horizonlar çok az kireçli olmasına karşın, ana materyalin marn karıșımı nedeniyle kireç oranı önemli derecede artmaktadır. Toprak reaksiyonları nötr ile nötre yakın hafif alkalin reaksiyonludur. Toprakların tuzluluk problemleri bulunmamaktadır (Tablo 3).

Toprak taksonomisine göre Lithic Haplustept olarak sınıflandırılan Damlaburun-2 serisi, altere olmuş kum taşı ve silt taşı özellikli ana materyal üzerinde oluşmuş, orta derinlikte ve iyi drenajlı topraklardır. Bu seri 792 da yayılım alanı ile toplam alanın \% 14.6'sını oluşturarak alanın üçüncü büyük serisini oluşturmaktadır. \% 20-30 eğime ile dik arazilere sahiptirler. Toprakların tuzluluk ve erozyon problemleri yoktur. Bünye yüzeyde kil tın bünyeye sahip topraklar bulunurken, derinlere doğru kil miktarı oldukça azalmakta, özellikle ana materyalin etkisi ile kumlu tına dönüşmektedir. Bünyedeki bu değişim KDK ve yarayışlı su tutma kapasitelerini de etkileyerek azalmalarına neden olmakta ve sirasiyla 14.2-34.4 $\mathrm{cmol} \mathrm{kg}^{-1}$ ile \% $9.4-19.8$ arasında değişmektedir. Topraklar kireçli olup \% 0.87-2.77 arasında değişmekte, organik madde ise yüzey toprağında \% 4.02 iken, bu oran derinlere doğru çok fazla azalma göstermekte ve \% 0.57 olmaktadır (Tablo 3). Toprakların profil boyunca ana spektral renkleri 2,5 Y' dir.

Ayrışmaya uğramış yumuşak kil taşı üzerinde oluşmuş olan Hasantepe Serisi toplam alan içerisinde 658 da alan ile \% 12'lik alanı oluşturmaktadır. Toprak taksonomisine göre Ömerinyeri serisinde olduğu gibi ultisol ordosunda fakat Typic Haplustult alt gurup içerisinde sinıflanmaktadır. Bu seri toprakları \% $12-20$ eğimli, dik arazilerden oluşmaktadır. Yüzeyde kil tın bünyeye sahip olan seri toprakları $18 \mathrm{~cm}$ 'den sonra kil miktarındaki artış ile kili genetik horizonlar killi bünyeye dönüşmektedir. Kil birikim katlarda ayrıca strüktüral değişimle beraber yarı köşeli blok yapılar oluşmaktadır. Kildeki artış topraklar zayıf drenaj ve yüksek KDK'ne neden olmaktadır. Organik madde yüzeyde $\% 2.26$ olarak tespit edilmiş, alt derinliklere doğru ise bu oran önemli ölçüde azalma göstermiştir. Tuzluluk problemleri bulunmamaktadır. Kireç tüm profilde hemen hemen homojen dağılım göstermekte olup \% 1 dolaylarındadır (Tablo 3).

Toprak taksonomisine göre Typic Dystrustept olarak sinıflandırılan Gürgenlikdere serisi; ayrışmaya uğramış yumuşak kil taşı üzerinde oluşmuş, derin ve zayıf drenajlı topraklardır. Profil $\mathrm{Ap} / \mathrm{Bw} 1 / \mathrm{Bw} 2 / \mathrm{BC} / \mathrm{C} 1 / \mathrm{C} 2$ şeklinde horizon dizilimi göstermektedir. Tanı horizonu olarak cambic horizona sahiptir. Bu alanlardaki topraklarda da genç topraklara nazaran strüktür oluşumları nedeniyle pedogenetik olayların etkisi biraz daha fazladır. Bu seri 1208 da yayılım alanı ile toplam alanın \% 22.1'ni oluşturarak, alanın en büyük serisini oluşturmaktadır. \% 12-20 eğime ile dik arazilere sahiptirler. Yüzeyde profil kil tın bünyeli iken, derinlere doğru 25-96 cm arasında kil miktarı bir miktar artarak ağır bünyeli olmaktadır. Tüm profil az kireçli olup, \% $1-3$ arasında değişmektedir. Toprak reaksiyon hafif asit ile hafif alkalindir. Toprakların KDK'ları \% 27.0- 36.4 $\mathrm{cmol} \mathrm{kg}^{-1}$ ve organik maddeleri yüzeyde \% 1.59 iken bu oran derinlerde \% 0.02 'lere düşmektedir (Tablo 3). Tuzluluk problemleri bulunmamaktadır.

Killi kireçtaşı-marn ve kum taşı ardalanmalı ana materyal üzerine oluşmuş İsmailinyeri serisi, toprak taksonomisine göre Typic Calciustept olarak sınıflandırılmakta ve 102 da alanla toplam alan içerisinde \% 1.9'luk kısmı ile alanın en küçük yayılım alanına sahip seriyi oluşturmaktadır. $\mathrm{Bu}$ toprak serisi \% 12-20 eğimle dik eğimli alanlardan oluşmakta olup, ayrıca seri kendi içerisinde eğim fazında farklılık göstererek eğimin \% 20'nin üzerine çıktığı çok dik alanları da kapsamaktadır. Yüzeyde topraklar kil tın iken tanı horizonunda kil, farklı ana materyallerde ise kil ve kumlu tın olmaktadır. $\mathrm{Bu}$ nedenle KDK'ları ve su tutma kapasiteleri yüksek olarak belirlenmiştir. $\mathrm{Bu}$ seri topraklarının pH'ları (6.68-8.01) hafif asit ile hafif alkalin arasında değişmektedir. Organik madde içerikleri, profilde derinlik arttıkça azalma göstermektedir. Kireç yüzey ve yüzey altı topraklarda oldukça düşük iken, ana materyalden kaynaklana sekonder kireç birimi nedeniyle \% 23'lere ulaşmaktadır (Tablo 3). Topraklarda tuzluluk ve erozyon problemleri yoktur.

\section{Sonuç ve Öneriler}

Havzanın başlıca arazi kullanım ve arazi örtü dağılımı toplam alanın \% 38.6'sı ile orman alanları oluştururken sırasıyla meyve bahçeleri (\% 35.5), meralık alanlar ( $\% 12.8)$, işlemeli tarım alanları (\% 9.5) ve yerleşim (\% 3.6) alanları oluşturmaktadır. Özellikle havzanın yarısına yakın $(\%$ 45) tarım yapılan alanlarında toprakların işlenmesi, sadece tohum yatağının hazırlanması amacıyla değil, uygun zaman ve aralıklarla yapıldığı takdirde yüksek bir verimin alınması amacıyla toprağın gevşetilmesi, su ve hava döngüsü ile yabancı ot kontrolü sağlanması amacıyla da yapılmaktadır. Çalışma alanı yüzey toprakları \% 38'lere ulaşan kil içeriklerine (İsmailinyeri ve Gürgenlikdere serileri) sahip iken, yüzey altı horizonlarda bu oran \% 51'lere ulaşabilmektedir (Hasantepe ve Önerinyeri serileri). Böyle topraklarda tohum yatağ hazırlanması sırasında toprak işleme zamanlarının 
iyi belirlenmesi gerekmektedir. Bunun için toprakların tavdayken işlenmesi gerekmektedir. Farklı bünyelere sahip toprakların farklı tav zamanları vardır. Killi toprakların bu zamandan önce işlenmesi durumunda toprakların fiziksel yapılarında önemli bozulmalar olurken, fazla nemli koşullarda işlenmeleri durumunda ise fazla çeki gücü istemesinin yanı sıra topraklarda iri kesekler meydana gelmektedir. Havalanmayı arttırmak, toprak yapısının gelişmesini sağlamak amacıyla topraklara organik madde ilavesi yapılmalıdır. Organik madde bir toprak düzenleyicisi olmasının yanı sıra toprakta mikroorganizma faaliyetlerini de arttırmaktadır. Ayrıca toprakların her yıl aynı derinlikte işlenmemesi gerekmektedir. Sürüm derinliğinin iki veya üç yılda bir topraklarda pulluk tabanı veya taban taşı oluşmaması için değiştirilmesi gerekmektedir. Aksi taktirde toprak içerisinde su ve hava döngüsünün engellenmesinin yanı sıra, bitki kökleri iyi bir gelişme gösteremeyeceği için verimde düşmelere neden olmaktadir.

Çalışma alanı genelde engebeli ve topoğrafik eğimin sıkça değiştiği bir arazi üzerinde yer almaktadır. $\mathrm{Bu}$ engebeli topoğrafyada yer yer küçükte olsa hafif eğimli alanlar mevcuttur. Çalışma alanı genel eğim dağılımına yönelik yedi sınıf içerisinde değerlendirdiğimizde, düz düze yakın ve hafif eğimli (\% 2-6) araziler toplam alana içerisinde \% 9.41'ni kaplarken, havzanın büyük bir kısmını ise (\% 64.06) çok dik ve çok sarp araziler oluşturmaktadır. Eğimin az olduğu alanlar genelde Madendere-1 ve Hasantepe serilerinde yer alırken, sarp eğimli (> \% 45) alanlar özellikle Madendere2, Ömerinyeri ve Güngenlikdere serilerinde hâkim durumdadır. Araştırma alanında \% 15-30 eğim aralığı en fazla yayılım göstermektedir. Çalışma alanının tarım yapılan alanların büyük bir kısmında meyve yetiştiriciliği yapılması nedeniyle toprak yüzeyleri bitki örtüsünce çok fazla kaplı olmamasının yanı sıra kuru tarım yapılan alanlarda nadasa bırakılması veya sürüm zamanlarında toprak yüzeyinin korumasız kalması nedeniyle erozyon tehlikesi altındadırlar. Özellikle havzanın kuzey kesimlerinde, eğimin fazla, arazi kullanımı genellikle kuru tarım ve meyvecilik yapılan seri topraklarında (Avluburun, Damlaburun-1 ve Gürgenlikdere serileri) bu sorun görülebilmektedir. Fakat, havzanın güney ve alçak kesimleri genellikle sık orman alanlarıyla kaplı olmaları nedeniyle eğimli olmalarına rağmen erozyon sorunu bulunmamaktadır. $\mathrm{Bu}$ nedenle özellikle tarım yapılan ve bozuk meralık alanlarda yağışı ı dönemlerde toprağı koruyucu bir bitki örtüsünün olmaması veya zayıflığı nedeniyle yüzeyde oluşan toprak materyali yüzey akışla taşınmasına neden olmaktadır. $\mathrm{Bu}$ yüzden bu alanlarda yer alan topraklar çok sığdır ve ana kayalar yer yer yüzeye kadar çıkmışlardır. $\mathrm{Bu}$ alanlarda oluşan ve oluşacak toprakların yerlerinde tutunmalarının sağlanması amacıyla ağaçlandırılması, toprak yüzeylerinde dayanıklı agregatların oluşturulması ve toprakların fiziksel kimyasal ve biyolojik özelliklerinde iyileştirmelerin yapılabilmesi amacıyla dönüme 2-3 ton ahır gübresi uygulayarak organik maddelerinin arttırılması gerekmektedir. Toprakların pH değerlerinin değişmesinde büyük ölçüde kireç içerikleri ile ayrışma sonucu açığa çıkan bazik katyonların miktarları belirlemektedir. Toprak serileri içerisinde İsmailinyeri serisi topraklarının profil boyunca yüksek kireç ve baz doygunluğundan dolayı en yüksek $\mathrm{pH}$ değerlerine (6.68-8.01) sahip iken, Hasantepe serisi ise profil içerisinde $\mathrm{CaCO}_{3}$ 'ın çok az ve düşük baz doygunluğuna sahip olması nedeniyle topraklar asitleşmekte, pH değerleri 4.81-5.86 arasında değişmektedir. Çalışma alanında profil boyunca kireç içeriği en yüksek olan İsmailinyeri serisinde oran \% 24'lara ulaşmaktadır. Bu durum özellikle kazık köklü bitkiler açısından bitki besin elementlerinin yarayışlılığını önemli ölçüde olumsuz yönde etkileyebilmektedir. Toprakta yüksek düzeyde bulunan kalsiyum iyonları, çoğu mikro elementler ve makro elementlerden özellikle de fosforla güç çözülebilir kompleks bileşikler oluşturmaktadır. Topraklarda toplam olarak yeterli miktarda mikro element bulunsa bile kalsiyum ile çözünemez bileşikler oluşturacaklarından, bitkiler bu mikro besin elementlerinden yeterince yararlanamazlar. Bunun sonucu olarak bitkilerde eksiklik kloroz semptomları ortaya çıkabilmektedir. Ayrıca diğer toprakların asitleşme eğilimleri olmakla beraber özelliklede Hasantepe serisinde bu durum daha da belirgin olarak tespit edilmiştir.

\section{Teşekkür}

$\mathrm{Bu}$ çalışma, Ondokuz Mayıs Üniversitesi BAP biriminin PYO.ZRT.1901.13.014 kodlu proje kapsamında gerçekleştirilmiştir. Çalışmaya Üniversitemizin vermiş olduğu desteklerinden dolayı teşekkür ederiz.

\section{Kaynaklar}

Akbaş, F., Yıldız, H., 2004. Toprak özelliklerinin haritalanmasında jeoistatistiksel tekniklerin kullanımı. 3. Coğrafi Bilgi Sistemleri Bilişim Günleri, 6-9 Ekim, İstanbul, s. 1-10.

Anonymous, 1954. Diagnosis Improvement of Salineand Alkali Soils. USDA Agri. Handbook, No: 60.

Anonymous, 1993. Soil Survey Manual, USDA. Handbook No: 18 Washington D.C.

Anonymous, 1999. Soil Taxonomy. A Basic of Soil Classification for Making and Interpreting Soil 
Survey. U.S.D.A Handbook No: 436, Washington D.C.

Bathgate, J.D., Duram, L.A., 2003. A geographic information systems based landscape classification model to enhance soil survey: A southern Illionis case study. Journal of Soil and Water Conservation Society, 58: 119-127.

Bouyoucos, G.J., 1951. A recalibration of the hydrometer for making mecanical analysis of soil. Agronomy Journal, 43: 434-438.

Dengiz, O., Sarıŏlu, F.E., 2011. Samsun ilinin potansiyel tarım alanlarının genel dağılımları ve toprak etüd ve haritalama çalıșmalarının önemi.
Anadolu Tarım Bilimleri Dergisi, 26(3): 241-253.

Hizalan, E., Ünal, H., 1966. Topraklarda Önemli Kimyasal Analizler. Ankara Üniversitesi, Ziraat Fakültesi Yayınları, No: 278.

Jackson, M.L., 1958. Soil Chemical Analysis. Prence Hall Inc. Englewood Cliffs, N.J. USA.

Rogowski, A.S., Wolf, K.J., 1994. Incorporation variability into soil map unit delineation. Soil Sci. Soc. Am. J., 58: 163-174.

Tüzüner, A., 1990. Toprak ve Su Analiz Laboratuvarları El Kitabı. T.C. Tarım Orman ve Köyişleri Bakanlığı, Köy Hizmetleri Genel Müdürlüğü, Ankara. 